\title{
ArcheoSciences
}

Revue d'archéométrie

$34 \mid 2010$

Varia

\section{The importance of lead in the silver production at Riotinto (Spain)}

L'importance du plomb dans la production d'argent à Riotinto (Espagne)

Lorna Anguilano, Thilo Rehren, Wolfgang Müller and Beno Rothenberg

\section{OpenEdition}

Journals

Electronic version

URL: https://journals.openedition.org/archeosciences/2833

DOI: 10.4000/archeosciences.2833

ISSN: 2104-3728

Publisher

Presses universitaires de Rennes

Printed version

Date of publication: 10 April 2010

Number of pages: $269-276$

ISBN: 978-2-7535-1407-2

ISSN: $1960-1360$

\section{Electronic reference}

Lorna Anguilano, Thilo Rehren, Wolfgang Müller and Beno Rothenberg, "The importance of lead in the silver production at Riotinto (Spain)", ArcheoSciences [Online], 34 | 2010, Online since 11 April 2011, connection on 27 January 2022. URL: http://journals.openedition.org/archeosciences/2833 ; DOI: https://doi.org/10.4000/archeosciences.2833 


\title{
The importance of lead in the silver production at Riotinto (Spain)
}

\author{
L'importance du plomb dans la production d'argent à Riotinto (Espagne)
}

\author{
Lorna Anguilano*, Thilo Rehren**, Wolfgang Müller *** \\ and Beno RothenberG ${ }^{* * * *}$
}

\begin{abstract}
The site of Corta Lago is located within Rio Tinto mining district, in the Huelva province, in the South-West of Spain. This region is geologically characterised by the presence of the Iberian Pyrite Belt, highly important for the concentration and the subsequent exploitation and production of several metals such as silver, copper, gold and manganese, since the Bronze Age up to few decades ago. This paper focuses on the exploitation of the North Lode of Cerro Salomon and in particular on the stratigraphic section of Corta Lago, spanning between the Phoenician period up to the second century AD, mainly highlighting the Roman period (200 BC-200 AD). The main goal is to distinguish the various slag typologies and reconstruct from them the differences between the silver smelting techniques and their possible reasons.

The importance of lead is well known within the cupellation process. However, for the silver production in Rio Tinto, lead has a crucial role already in the first step of the production: the smelting. Lead metal or a lead mineral is added to the first charge in the furnace with jarosite (containing a varying lead concentration), and gangue (quartz plus barite in varying ratios). The isotopic characterisation of the lead involved in the system seems to point to use of lead with different origins, sometimes local and sometimes "foreigner". This observation is further confirmed by the presence of Roman lead ingots with the stamp "Carthago" (stored at the Rio Tinto Museum). The lead isotope analyses have the aim to identify the possible area of provenance of the lead used for the smelting in Rio Tinto.
\end{abstract}

Résumé : Le site de Corta Lago est situé dans la ville de Rio Tinto, dans la province de Huelva, au sud-ouest de l'Espagne. Cette région est caractérisée par la présence de la ceinture pyritique ibérique, qui est la raison majeure de son importance dans la production de plusieurs métaux tels que l'argent, le cuivre, l'or et le manganèse, dès l'Âge du Bronze et ce jusqu'au siècle dernier.

Cette communication met l'accent sur l'exploitation du filon nord de Cerro Salomon, et s'appuie sur un profil continu de scories de la section de Corta Lago, par les Romains (200 BC-200 AD). Le but est de décrire les différentes typologies de scories d'argent dérivant de techniques distinctes de fusion du minerai. On connaît l'importance du plomb dans la coupellation. Cependant, dans le procès de production de l'argent à Rio Tinto, le rôle du plomb est crucial dès la première étape du procédé de fusion. Ce métal est en effet utilisé pour collecter l'argent, il a donc été ajouté à la première charge de minerai - dans le cas présent, de la jarosite, pauvre en plomb - et de gangue - quartz et baryte - dans le four.

Le plomb employé sur le site de Rio Tinto était en partie d'origine locale et en partie importé, suivant les périodes. Deux lingots de plomb ont par ailleurs été retrouvés : chacun d'eux conserve l'estampille caractéristique "Carthago ". Ils sont actuellement exposés au Museo Minero de Rio Tinto. Des analyses des isotopes du plomb ont été entreprises afin de déterminer les régions de provenance de ces différents "plombs".

Key words: Silver production, lead addition, slag, Antiquity, Rio Tinto.

Mots clé : Production de l’argent, addition du plomb, Antiquité, Rio Tinto.

\footnotetext{
* Experimental Technique Centre, Brunel University.

** Institute of Archaeology, University College of London.

*** Department of Geology, Royal Holloway, University of London.

**** Institute of Archaeo-Metallurgical Studies, London.
} 


\section{INTRODUCTION}

This paper focuses on the archaeo-metallurgical debris from Corta Lago, Riotinto, South-West Spain.

The site is located within a mining district known and exploited since the Late Bronze Age. This ore-rich district is the result of a regional tectonic event that led to the formation of the Iberian Pyrite Belt and characterizes the whole western part of the Sierra Morena to the border with Portugal and part of Portugal itself.

The deposit of the pyrite belt is characterized by sulphides ( dominant pyrite, sphalerite, galena and chalcopyrite, generally with accessory tetrahedrite-tennantite, cassiterite and pyrrothite, and numerous trace minerals including electrum - Leistel et al., 1998, 13). The deposit comprises different layers which from the bottom to the top are: sulphide stockworks and massive sulphides, showing the same parageneses mentioned above, and gossan. These three geological layers have been formed at the same time so they show the same isotopic signature (Marcoux \& Saez, 1994; Leistel et al., 1998; Marcoux, 1998). Between the massive sulphides and the gossan, the phenomena of oxidation and water infiltration formed a secondary enrichment layer (Davies, 1935, Rothenberg and Blanco-Freijero, 1981; Salkield, 1987; Barriga, 1990; Kassianidou, 1992; Hunt Ortiz, 2003). This enrichment layer is the one mainly exploited in antiquity for the production of silver and copper. The layer is characterized by a complex hydro-sulphate called jarosite or more accurately jarosites: $\mathrm{XFe}_{3}\left(\mathrm{SO}_{4}\right)_{2}(\mathrm{OH})_{6}$ where $\mathrm{X}$ can be $\mathrm{K}, \mathrm{Na}, \mathrm{NH}_{4}, \mathrm{Ag}$ and $\mathrm{Pb}$. Depending on the main cation accompanying the iron, the jarosite has a different dominant colour, useful in Antiquity to recognise the vein to be exploited.

\section{Archaeology}

Modern quarrying in the Riotinto area during the last century led to the discovery of mines and sections of ancient slag heaps. More than thirty years ago, the Huelva Archaeo-Metallurgical Project, coordinated by Prof. Beno Rothenberg, carried out a survey in the area and discovered different sites from different historical periods. The site of Corta Lago is, stratigraphically, one of the most complete, covering from the LBA to the $2^{\text {nd }}$ century AD. Several seasons cleaned and uncovered a section of metallurgical debris several metres deep, truncated at the top and covered by a $2^{\text {nd }}$ century Roman wall, so we do not have evidence of later activity (Fig. 1).
Two layers of the section were radiocarbon dated; layer 50 dated to the $1^{\text {st }}$ century $\mathrm{BC}$ and the layer 92 dated to the $1^{\text {st }}$ century AD. Stylistic analyses of the ceramic allow interpolation of these two dates thus dating the whole section: - layers 91 to 99 Imperial;

- layers 67 to 92 Republican tapped slags period II;

- layers 50 to 66 Republican plate slags period;

- layers 114 to 119 and 1 to 50 Republican tapped slags period I;

- layers 108 to 113 Iberians;

- layers 100 to 107 Phoenician.

It should be noted that layer 101 to 119 are physically below layer 1, while layers 1 to 100 follow upon each other.

\section{Results and Process}

The production of silver from jarosite involves a completely different chemical system compared to those we are used to when silver is associated to primary or secondary lead minerals such as galena or cerussite (Laurion - Conophagos, 1980, Rehren and Prange, 1998).

In this case the main cation is iron and the system is ironsilicate dominated, while in other cases the iron compounds if present, may be associated to lead silicate.

It is common knowledge that lead is a silver collector, and from a bullion of silver rich lead, through the cupellation we obtain silver.

In the iron-dominated jarosite system however there is not sufficient lead to create a lead (silver) bullion during the smelting, hence and excess of lead must be added in order to ensure the complete collection of the silver.

One possible source of lead is the plumbojarosite, part of the jarositic earths beneficiated for the production of silver, so the primary mineral. However the richness of plumbojarosite in the veins varies widely between 3 and 32\% (Hunt Ortiz, 2003). This high variance of lead concentration in the mineralization could explain the discovery of archaeological silver free lead ingots in the area. The question of the origin of this extra lead is a key part of our understanding of Roman period silver extraction and some possible interpretations will be discussed later on in this paper.

\section{Variation of the process through time}

This study is focused on the reconstruction of the processes and the comparison between the four different technological periods recognised in the section: pre-Roman, Republican tapped slag (I and II), Republican plate slag, and Imperial tapped slag. The reconstruction of the processes is 


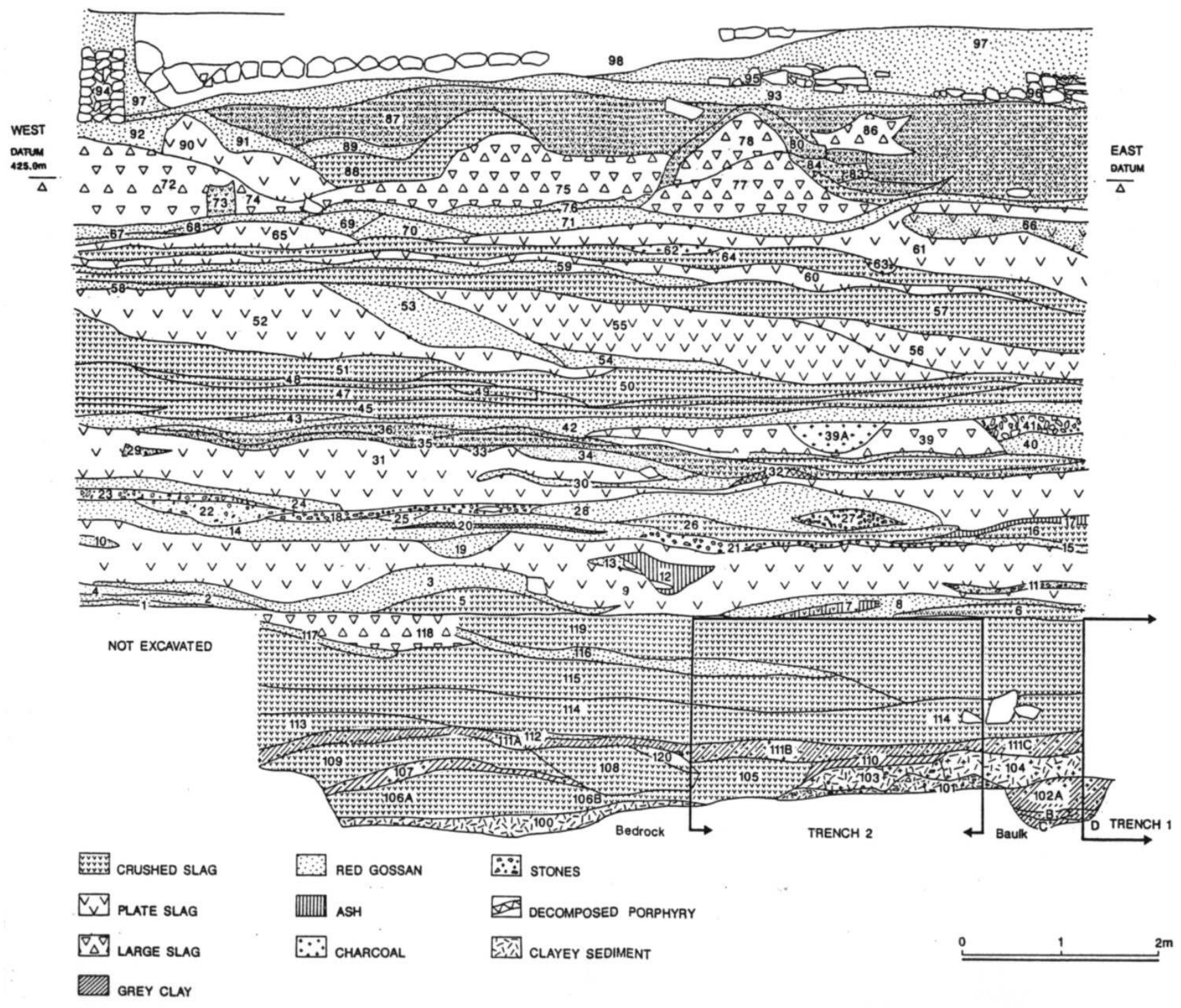

Figure 1: layers of tapping separated by a thin magnetite layer.

Figure 1: Niveaux of coulées séparées l'un de l'autre avec un fin niveau de magnétite.

through chemical-mineralogical analyses of the slags. Bulk analyses is used to reconstruct the charge and the temperature of the process and analyses of the new-formed phases to used to reconstruct other parameters of the process, such as fugacity of oxygen, liquidity of the system, speed and method of cooling.

The Bronze Age layers are characterized by so-called freesilica or ball slags, which are found also in other sites in the same region, for instance Monte Romero (Kassianidou, 1992). These slags are characterized by the presence of residual crystals of quartz and barite, already visible at the macroscopic scale. The main mineral is a feldspar-like mineral with the approximate formula $(\mathrm{K}, \mathrm{Ba}, \mathrm{Fe}, \mathrm{Ca}, \mathrm{Pb})$ $\mathrm{Al}_{2} \mathrm{Si}_{2} \mathrm{O}_{8}$, found associated with pyroxene $\left(\mathrm{Ca}(\mathrm{Mg}, \mathrm{Fe}) \mathrm{Si}_{2} \mathrm{O}_{6}\right)$, cerussite and lead oxide. The crystals are fine in size which suggests a fast cooling, but the structure of the crystals (from hopper to polyhedral) suggest a slow cooling (Donaldson, 1976, Ettler, 2009). The explanation is possibly a low quantity of liquid in the cavities between the rigid structure of the solid crystals at the moment of crystallisation. The temperature of the liquidus can be calculated at $1100^{\circ} \mathrm{C}$. Quartz and barite residual crystal show low indication of chemical reaction with the melt, and the author agrees with Tylecote hypothesis that gangue "sand" was added to thicken the 
slag "like a sponge with water" in order to help its removal (Tylecote 1987, 306-307).

The Phoenician layers are characterised by crushed slags. These slags are mainly constituted by olivine, with $\mathrm{H}$-chain morphology, which suggests a fast cooling. Crystallized magnetite is also present, disseminated in the slag and with a skeletal structure, indicating crystallization in the oxidizing condition when the amount of residual liquid was very low, since the length of the olivine suggests a begging of crystallisation already inside the furnace. The glass phase corresponds to a pyroxene-like composition. Residual aggregates of quartz were detected. Poly-metallic prills were detected $(\mathrm{Pb}, \mathrm{Sn}, \mathrm{Cu}, \mathrm{Zn}, \mathrm{Ag}, \mathrm{Sb}$ ) suggesting the use of jarosite mixed with poly-metallic sulphides as raw material. The system was not completely liquid, as indicated by the residual (non-reacted) quartz. The association of a glass phase with pyroxenitic composition, the skeletal (H-chain morphology) of the olivine and the residual quartz seem to suggest a rapid cooling. The temperature of the smelting can be estimated at $1100^{\circ} \mathrm{C}$.

The Iberians layers are predominantly characterised by crushed slags. The mineralogical association is dominated by fayalite with very fine $\mathrm{H}$-shaped habit, indicating fast crystallisation and corroborating the indication given by chemical uniformity resulting from area analyses, even if residual barite is detected, suggesting then an excess of this component. The bulk composition suggests a smelting temperature of $1100^{\circ} \mathrm{C}$.

The Republican period can be further divided in two different phases: the tapped slag and the plate slag phase.

The first phase is the tapped slag: the samples are characterized by the typical lava-like flow slags, and the tapping hole size can be estimated at c. $1 \mathrm{~cm}$ diameter. The slags were tapped one on top of the other and the different layers are recognisable because of an oxidation layer of magnetite, indicating a short length of time between the different tapping (Fig. 2).

Olivine is the main mineral and shows a skeletal structure and a spinifex texture, representing a very fast cooling. The system was completely liquid with no excess of any of the components, and the temperature of the smelting can be estimated at $1100^{\circ} \mathrm{C}$.

The second phase is characterized by plate slags. These slags derive from a process of tapping in a fore-hearth and then "peeling" away the slag layer by layer from there. Olivine is still the main mineral, associated in this case with a feldspathoid-like mineral, with the formula $(\mathrm{K}, \mathrm{Fe}, \mathrm{Ba}) \mathrm{AlSi}_{2} \mathrm{O}_{6}$. The olivines are skeletal, but their size is increased compared to the first phase and there is no spinifex texture visible, so the cooling rate has decreased relative to the first phase. The top

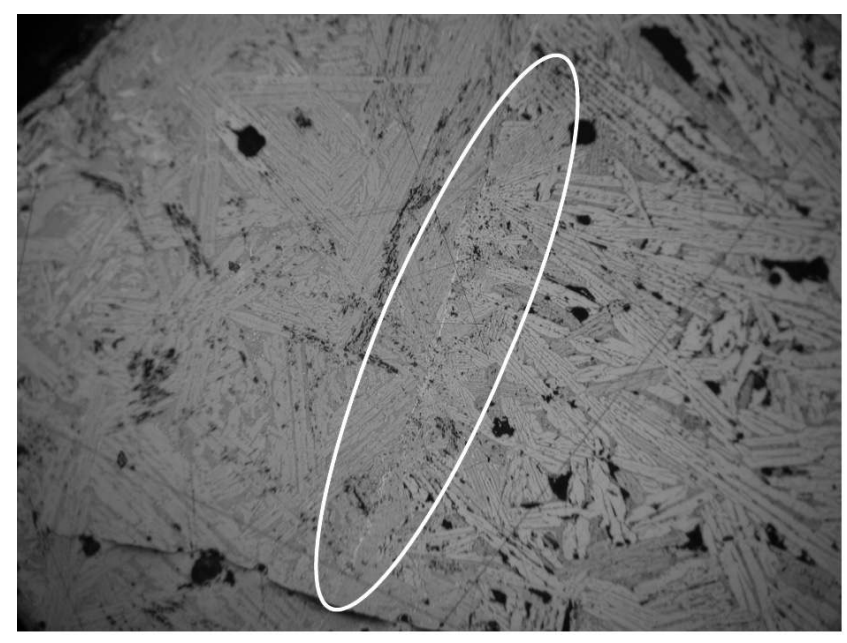

Figure 2: Layers of olivines crystallized from two different smelting events.

Figure 2: Niveaux d'olivines cristallisées de deux différents événements de fusion.

and bottom surfaces are characterised by dendritic magnetite indicating the formation of top and bottom "crusts" within which densely liquid material was more slowly crystallising. The system was completely liquid, no residual components are detected and the temperature of smelting is calculated at $1100^{\circ} \mathrm{C}$. The samples from this phase are the ones with lowest concentration of silver.

The Imperial phase is also a tapping phase, but in this case we observe an increase in the lava-flow like structures typical of the tapping. This can be linked with the size of the tapping hole diameter which can be estimated at $2 \mathrm{~cm}$ (while it could be estimated around $1 \mathrm{~cm}$ in the previous phases). The main mineral is olivine but in this case two families of olivines are detected, a first crystallised phase has hopper structure indicating a slower cooling rate (Donaldson, 1976), starting in the furnace, and a second family with skeletal small size habit which crystallised within the residual liquid at the moment of the tapping. This observation is parallel to the observation of high variance in area analyses, since the first crystallisation would impede the movement of the chemicals in such a semirigid system. More layers of slag were tapped one on top of the other, indicated by the fact that the spinifex structure of the olivine at the surface of every tapping event can be seen inside the analysed samples. In this case there is no presence of oxidation layers between the different tapping events (Fig. 3) indicating a rapid succession. This too is a completely liquid system with no component in excess and with a smelting temperature of around $1100^{\circ} \mathrm{C}$.

The chemical composition of the material found in the different periods is fairly homogenous: the major oxides 


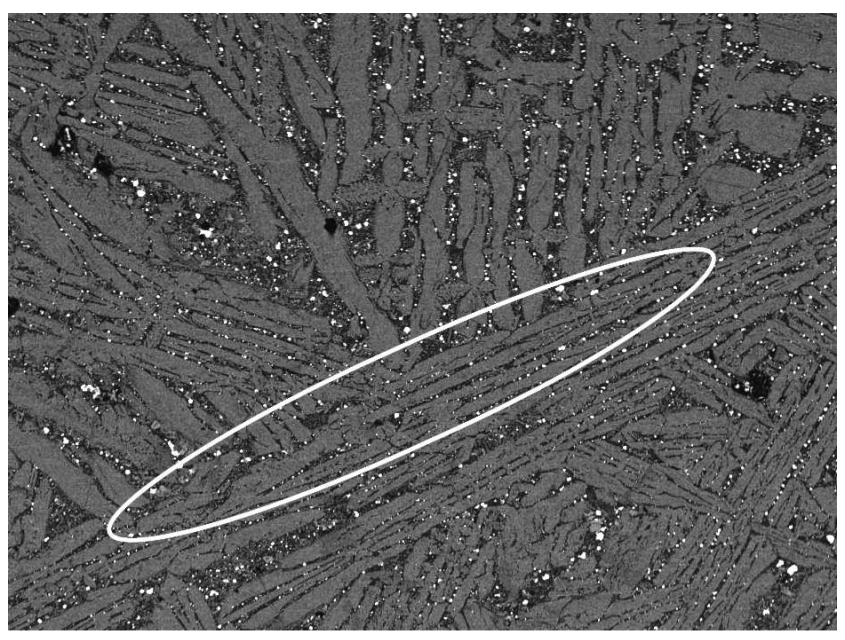

Figure 3: Corta Lago Section, drawn by Brenda Craddock. Figure 3: Section stratigraphique de Corta Lago (Brenda Craddock).

have the average of: $\mathrm{SiO}_{2} 20-30 \% \mathrm{Fe}_{2} \mathrm{O}_{3} 50-60 \%, \mathrm{CaO}$ $0.1-3 \%, \mathrm{BaO} 1-4 \%, \mathrm{Al}_{2} \mathrm{O}_{3} 3-6 \%$ corresponding to the field of stability of olivine in the diagram $\mathrm{SiO}_{2}, \mathrm{Fe}_{2} \mathrm{O}_{3}$, $\mathrm{Al}_{2} \mathrm{O}_{3}$, which is the minimum temperature field. The raw material is always the jarosite and its quartz/barite gangue mixed with poly-metallic sulphides (association typical of the enrichment zone of the massive sulphide in the Iberian Pyrite Belt). During the Roman phases it is observed complete understanding of the proportions between these two materials indicated by the complete liquidity of the system, while during the pre-Roman periods the proportion was not completely standardised, as shown by the presence of residual gangue material in the slags. Improvement in the loss of silver between the Bronze Age and the Phoenician and Roman periods is noticeable since it decreases by 1 to 2 orders of magnitude.

The temperature of the process is around $1100^{\circ} \mathrm{C}($ Geller et al., 1934 and 1943).

During the Roman period we observe some technological improvements.

The first macroscopic change is the plate slags period. At this time there is a transition from free tapping to forehearth tapping. The capability of recovering silver is improved, and this change may be due to a geological constraint (ore poorer in lead, richer in silver).

During the two tapping periods we identify two technological changes. The first one is the increase in size of the tapping hole from around $1 \mathrm{~cm}$ to $2 \mathrm{~cm}$ and this is possibly connected with an increase in the furnace size. The second change is the absence of the brief temporal gap between successive tapping during the Imperial period, a gap that is visible during the first
Republican period. Both changes indicate an increased rate of production in the later period.

\section{Origin of lead addition}

Three ingots have been analysed during this project, two of them are lead ingots with small calcium impurity, while the third one is a copper iron sulphide ingot $(\mathrm{Cu} \approx 40 \% ; \mathrm{Fe}$ $\approx 30 \%$; $\mathrm{S} \approx 30 \%$ ).

Thirty three slag samples, nine semi-reacted ores and 3 ingots have been analysed by MC ICP-MS to trace their isotopic signature in order to give an insight into the origin of the extra lead.

The results show a mixing line of isotopic signature (Fig. 4). Comparing the slag isotopic data with a preliminary selection of ore isotopic data, one extreme of the mixing line coincides with the isotopic signature of the massive sulphide of the pyrite belt (Fig. 4, Gale \& Stos-Gale, 1989), while the other extreme (where most of the Phoenician and the Republican plate slags are plotted), looks convincingly similar to the Cartagena isotopic signature. This hypothesis of an added component of Carthagenean lead is also supported by the archaeological evidence of two ingots with

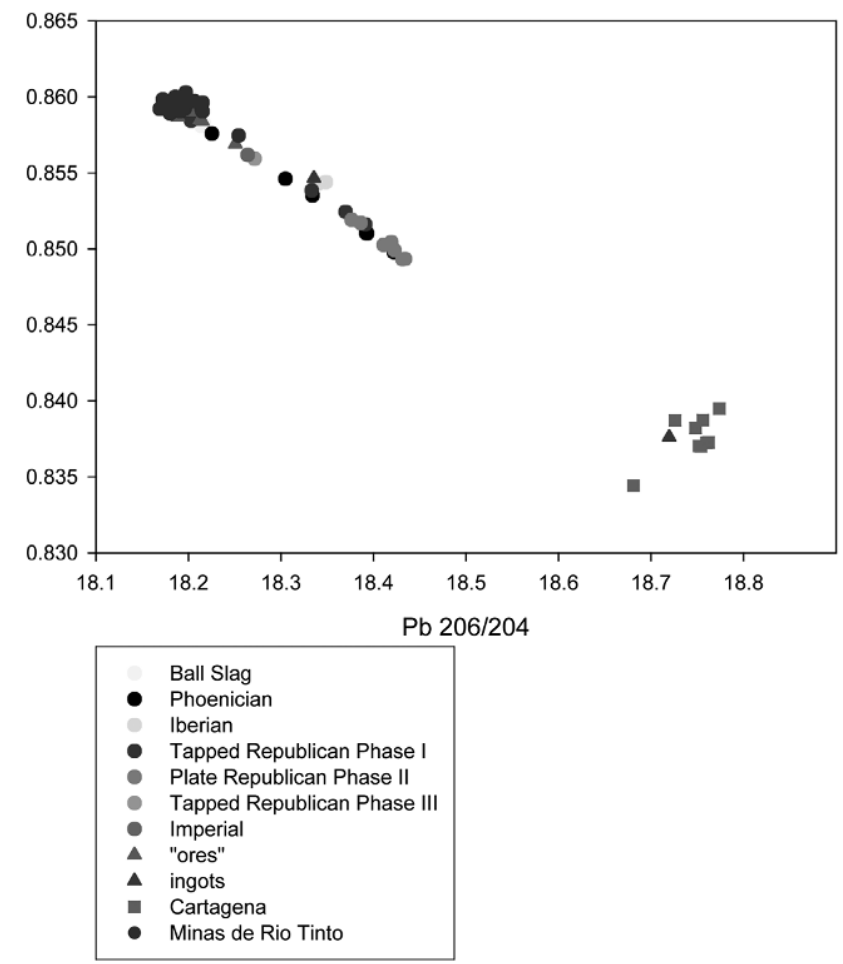

Figure 4: (Voir planche couleur) Diagram of the Isotope results for the slags, the ingots and the ores.

Figure 4: (See colour plate) Diagramme des isotopes du plomb dans les scories, lingots et minerai. 


\begin{tabular}{|c|c|c|c|c|c|c|}
\hline & & $\mathrm{Pb} 206 / \mathrm{Pb} 204$ & $\mathrm{~Pb} 207 / \mathrm{Pb} 206$ & $\mathrm{~Pb} 208 / \mathrm{Pb} 206$ & Pb207/Pb204 & $\mathrm{Pb} 208 / \mathrm{Pb} 204$ \\
\hline & RT24n7 & 18.21391072 & 0.858165236 & 2.097090852 & 15.630545 & 38.19622554 \\
\hline free silica & RT24n8 & 18.21662105 & 0.858219512 & 2.097255374 & 15.63385962 & 38.20490639 \\
\hline & RT24n9 & 18.21400354 & 0.858082011 & 2.096757518 & 15.62910879 & 38.19034886 \\
\hline & & & & & & \\
\hline & RT39 & 18.33401159 & 0.853515656 & 2.09709022 & 15.64836593 & 38.44807641 \\
\hline & RT35 & 18.22524627 & 0.857572023 & 2.103145584 & 15.6294613 & 38.33034621 \\
\hline phoeniciar & RT16 & 18.42200651 & 0.849780253 & 2.093794032 & 15.65465735 & 38.57188728 \\
\hline & RT5 & 18.39296438 & 0.851011906 & 2.094900733 & 15.65263168 & 38.53143457 \\
\hline & RT22 & 18.30472421 & 0.854609736 & 2.098442568 & 15.64339553 & 38.41141248 \\
\hline Ibero-Puni & RT55 & 1834853181 & 0.854397001 & 2.100 & 15.67693056 & 38.53799161 \\
\hline & RT56 & 18.3397286 & 0.854292182 & 2.100160658 & 15.66748676 & 38.51637647 \\
\hline & & & & & & \\
\hline & RT84 & 18.39184404 & 0.851041864 & 2.094854208 & 15.65222923 & 38.52823188 \\
\hline & RT75 & 18.19192383 & 0.859373055 & 2.101843523 & 15.63364916 & 38.23657728 \\
\hline Republicaı & I RT86 & 18.1831303 & 0.859460532 & 2.101890401 & 15.62768283 & 38.21894704 \\
\hline tapped & RT85 & 18.39100612 & 0.851608149 & 2.096508439 & 15.66193068 & 38.55689954 \\
\hline & RT74 & 18.20286571 & 0.858427249 & 2.10148801 & 15.62583594 & 38.25310403 \\
\hline & RT83 & 18.20166918 & 0.858834554 & 2.101471115 & 15.63222243 & 38.25028202 \\
\hline plate & RT79 & 18.4313963 & 0.849316149 & 2.092936249 & 15.65408254 & 38.57573744 \\
\hline & RT82 & 18.41084044 & 0.850254418 & 2.094158887 & 15.65389842 & 38.55522513 \\
\hline republican & RT72 & 18.27138282 & 0.855930185 & 2.098732738 & 15.63902808 & 38.34674928 \\
\hline tapped II & RT77 & 18.19253909 & 0.859147678 & 2.101566292 & 15.63007771 & 38.23282693 \\
\hline & & & & & & \\
\hline & RT24n2 & 18.26397862 & 0.856175271 & 2.098206946 & 15.63716685 & 38.32160681 \\
\hline & RT24n3 & 18.18298129 & 0.859468975 & 2.101709331 & 15.6277083 & 38.21534144 \\
\hline Imperial & RT24n4 & 18.18309588 & 0.859405213 & 2.101229364 & 15.62664739 & 38.20685498 \\
\hline & RT24n5 & 18.18896504 & 0.859312504 & 2.101083789 & 15.6300051 & 38.21653959 \\
\hline & RT24n6 & 18.18828095 & 0.859174516 & 2.101588061 & 15.62690749 & 38.22427408 \\
\hline
\end{tabular}

Table 1: Lead isotope analyses of the slag samples from Corta Lago.

Tableau 1 : Analyses isotopiques du plomb dans les scories de Corta Lago. the stamp "Carthago" recorded in the literature (Domergue $1987,1990)$. The isotopic signature of the two lead ingots confirms the mixing line Cartagena/Rio Tinto mines, and the matte ingot confirms the Cartagena isotopic signature. The two ingots purified in silver through cupellation represent the stock of lead recycled in the system. The matte ingot represents a waste possibly arrived from Cartagena with the load of lead ingots, and recognised and discarded by the smelters in Rio Tinto. This result suggests two possibilities: during these two periods either a vein particularly poor in plumbojarosite was excavated or the ancient smelters were adding extra lead to be on the safe side for a complete collection of silver. In order to distinguish between these possibilities we studied the crystallographic structure of the jarosite. The organisation of the ions $\mathrm{Fe}, \mathrm{O}, \mathrm{S}$ and $\mathrm{H}$ is such that big cavities are left to be occupied by the other cations $\left(\mathrm{K}, \mathrm{Na}, \mathrm{NH}_{4}\right.$, and $\mathrm{Pb}, \mathrm{Ag}$ occupies a different lattice position). Considering the ratio $\mathrm{Na}_{2} \mathrm{O} / \mathrm{PbO}$ and $\mathrm{K}_{2} \mathrm{O} / \mathrm{PbO}$ (Fig $5 \mathrm{a}$ and $5 \mathrm{~b}$ ), for those slags for which the addition of lead metal is proved by the isotopic signature we observe that the Republican plate slags are relatively more alkali enriched. The relative enrichment in alkali can be read as an effective decrease of plumbojarosite in the vein, there is no evidence for the alkali to be the results of a bigger use of fuel. This lack of plumbojarosite had to be compensated by the addition of lead metal from elsewhere. Such a fine understanding of the ore would indicate a routine assaying of the ore for both lead and silver. We do not observe any difference in the ratio alkali/PbO for the Phoenician slags. The homogeneity of the Phoenician slags with the other slags in this respect but the difference in their isotopic signature can be explained by considering that during the Phoenician period extra lead was possibly added despite a sufficient richness in plumbojarosite of the vein. Unfortunately the analysis of the ratio $\mathrm{Ag} / \mathrm{Pb}$ does not give information about the richness in silver of those veins poorer in plumbojarosite.

\section{Conclusions}

The metallurgical processes during the periods considered have the same raw material (jarosite, poly-metallic sulphides, quartz and barite) plus a varying amount of extra lead metal. The temperature is estimated to around $1100^{\circ} \mathrm{C}$. 


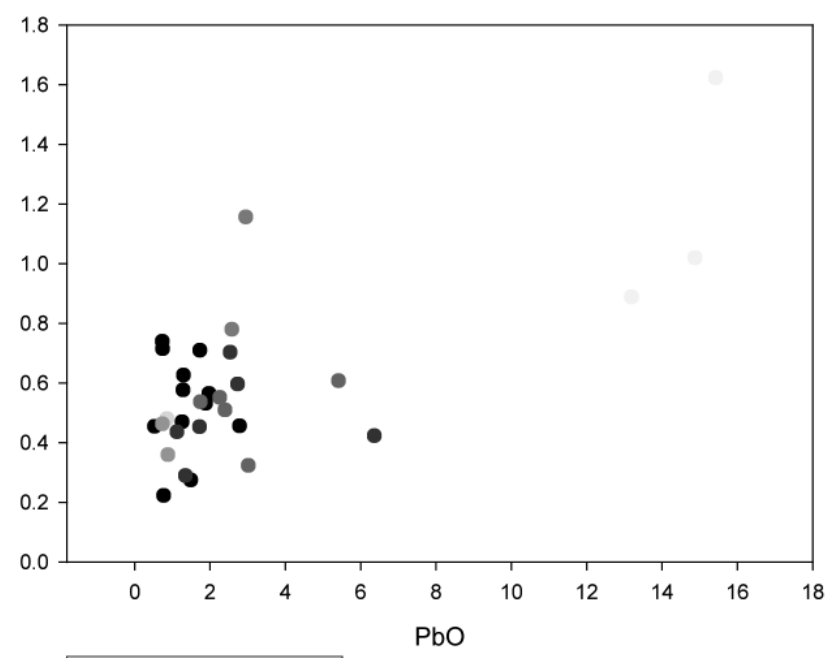

\begin{tabular}{|ll|}
\hline Bronze Age \\
- & Phoenician \\
Iberian \\
- Tapped Republican \\
Plate Republican \\
- Republican/Imperial \\
\hline
\end{tabular}

Figure 5a: (Voir planche couleur) Diagram $\mathrm{PbO} / \mathrm{Na}_{2} \mathrm{O}$ for the slag samples.

Figure 5a: (See colour plate) Diagramme $\mathrm{PbO} / \mathrm{Na}_{2} \mathrm{O}$ dans les scories.

The main technological change reconstructed between the pre-Roman and Roman periods is the standardisation of the process and the understanding of the correct proportion ore/ gangue and the firing time. The complete liquidity of the system achieved in this way resulted in a decrease in the loss of silver. The main difference between the Phoenician and the Roman periods is an increased understanding of the ore, possibly by regular assay, and the import of lead metal only when the plumbojarosite in the ore was not sufficient.

Within the Roman period the production increased in scale and the diameter of the tapping hole doubled reflecting a probable increase of the size of the furnace. There was also continuity of production with no detectable temporal gap between successive tappings in the later period.

The preliminary isotope data do not appear to give a decisive distinction in the use of extra lead in different periods, even though it appears that during different periods the source of extra lead was always the same one, possibly Cartagena. The main difference (not completely coincident with the different phases) is the amount of extra lead metal used, due possibly to the varying richness in plumbojarosite of the exploited vein. Considering that most of the data coming from the Phoenician and the Republican plate slag period are at the far end of the mixing line, we could argue that in these two periods more extra lead metal was used. If
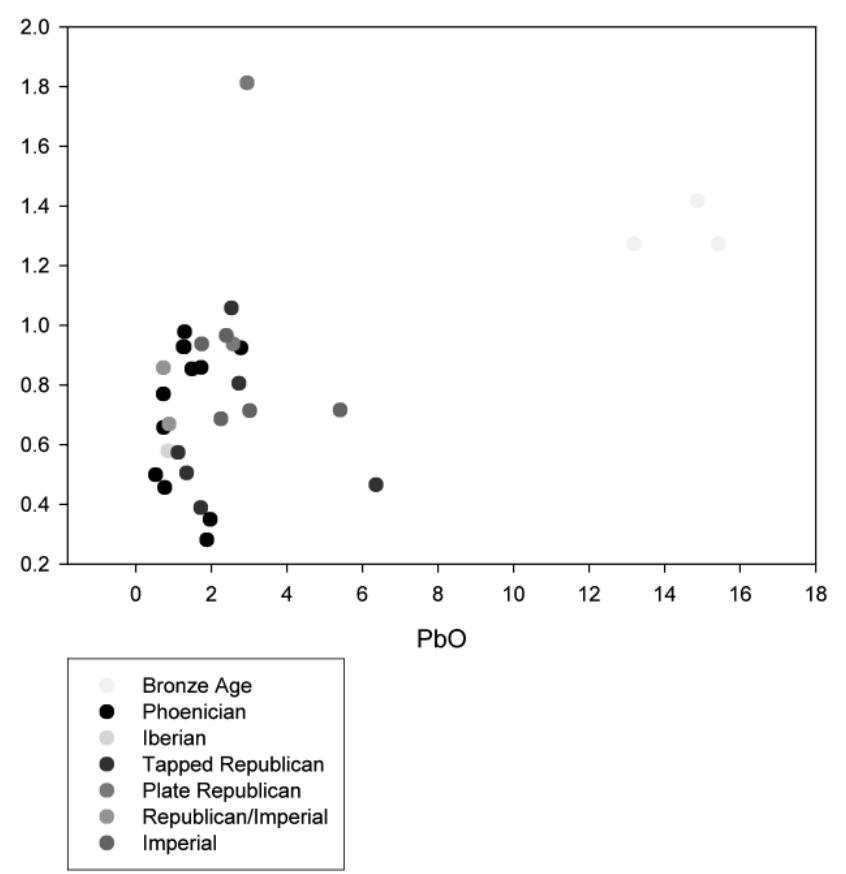

Figure 5b: (Voir planche couleur) Diagram $\mathrm{PbO} / \mathrm{K}_{2} \mathrm{O}$ of the slag samples.

Figure 5b: (See colour plate) Diagramme $\mathrm{PbO} / \mathrm{Na}_{2} \mathrm{O}$ dans les scories.

we consider the Phoenician slag samples we do not notice any relative enrichment in alkali that would suggest a deficit of plumbojarosite in the vein. From this we can deduce that Phoenician smelters were adding extra/imported lead metal even when it was not required.

Considering the skills and the metallurgical knowledge identified in the first Republican period, the lead isotope signature found for the Republican plate slags may be related to veins poorer in plumbojarosite and needing a larger addition of lead metal from elsewhere; an hypothesis confirmed by the relative enrichment in alkali of these slags.

The puzzling period is what we called the Republican plate slags period. What was the need for this change in tapping process? Did the production slow down? Several reasons can be speculated: a more difficult mining situation that would request a larger capital investment; the need for more material coming from another region as indicated by the isotope results; a lack of capital to invest due to a political or socio-economical situation. The $1^{\text {st }}$ century $\mathrm{BC}$ coincides with the political instability of the Roman Republic, followed by the stability brought by the settlement of the Empire. This period is also characterised by the presence of the procurator metallorum and a panel pf private investors (Avery, 1974), sharing the ownership and the exploitation of the mines. This situation changes during the Empire when 
the State intervenes in the ownership and the amount of capital increases.

\section{Acknowledgment}

Paul Craddock, Brenda Craddock, Phil Andrews and John Merkel helped a lot with their memories and documentation. Richard Harrison work on the archaeological stratigraphy and summary of all the excavation notes was immensely important for my project.

We are very grateful to Prof. Aurelio Perez Macias and Prof. Reinaldo Saez (University of Huelva) for the support, the company and the communications during my field trip to the Huelva Province, and to all the staff of the Museo Minero de Rio Tinto and in particular to Aquilino Delgado Dominguez for the help to select the material in the museum storage and the visits to the mine and the joyful company during my stay in Rio Tinto.

We thank Gilberto Artioli for the use of XRD at the Department of Mineralogy at the University of Milano and Monica Dapiaggi for all the advices for the use of the machine. The XRF, SEM and OM analyses were done at the Wolfson Archaeological Science Laboratories at the Institute of Archaeology UCL, with the important co-operation of Simon Groom (XRF laboratory supervisor) and Kevin Reeves (SEM laboratory supervisor). The MC-ICP-MS analyses were done at the Geology Department, Royal Holloway, University of London.

This project is funded by the European Union under a Marie Curie Host Fellowship for Early Stage Research Training, contract MEST-CT-2004-514509.

\section{References}

Avery, D., 1974. Not on Queens' Victoria Birthday.

Barriga, F. J. A. S., 1990. Metallogenesis in the Iberian Pyrite Belt. In Dallmeyer R. D. and Martinez Garcia E. (eds.), PreMesozoic Geology of Iberia, Springer-Verlag, 369-379.

Conophagos, 1980. Le Laurium Antique et la technique grecque de la production de l'argent, Athens.

Davies, O., 1935. Roman Mines in Europe, Oxford.

Donaldson, C. H., 1976. An experimental investigation of olivine morphology Contrib. Mineral. Petrol., 57187.
Domergue, C., 1987. Catalogue des mines et de fonderies antiques de la Peninsule Iberique. 2 Vols. Publications de la Casa de Velazquez. Madrid.

Domergue, C., 1990. Les Mines de la Peninsule Iberique dans l'antiquité Romanine. Collection de l'École Française de Rome, 127.

Ettler, V., Cervinka, R. and Johan, Z., 2009. Archaeomoetry, volume 51, Issue 6, 987-1007.

Gale, N. H. and Stos-Gale, Z. A., 1989. Some Aspects of Early Cycladic Copper Metallurgy. In Mineria y metalurgia de las antiguas civilizaciones Mediterraneas y Europeas, I: 21-36. Ministero de Cultura, Madrid.

Geller, R. F. and Bunting, E. N., 1943. J. Research Natl. Bur. Standards 31, 261. RP 1564.

Geller, R.F., Creamer, A.S. and Bunting, E.N., 1934. J. Research Natl. Bur. Standards, 13 [2] 243; RP 705

Geological-Mining Map of Andalusia 1985. (MGMA).

Hunt Ortiz, M. A., 2003. Prehistoric Mining and Metallurgy in South West Iberian Peninsula BAR International Series 1188.

Kassianidou, V., 1992. Monte Romero (Huelva), a Silver Producing Workshop of the Tartessian Period in SW Spain. Unpublished $\mathrm{PhD}$ thesis University College of London.

Leistel, J. M., Marcoux, E., Thiéblemont, D., Quesada, C., Sànchez, A., Almodòvar, G.R., Pascual, E. and Sàez, R., 1998. The volcanic-hosted massive sulphide deposits of the Iberian Pyrite Belt. Mineralium Deposita. Vol. 33 N. 1-2, 2-20.

Marcoux, E., 1998. Lead isotope systematics of the giant massive sulphide deposits in the Iberian Pyrite Belt. Mineralium Deposita. Vol. 33 N. 1-2, 45-58.

Marcoux, E. and SAEZ, R., 1994. Geoquimica isotopica de plomo de las mineralizaciones hidrothermales tardihercinicas de la Faja Piritica Iberica. Bol Soc Esp Mineral. N. 17-1. 202-203.

Rehren, Th. and Prange, M., 1998. Lead metal and patina: a comparison. In Rehren Th., Hauptmann A. and Muhly J. (eds.), Metallurgica Antiqua, In Honour of Hans-Gert Bachmann and Robert Maddin, 183-196.

Rothenberg, B. and Blanco-Freijeiro, A., 1981. Ancient Mining and Metallurgy in South-West Spain, IAMS.

Salkield, L. U., 1987. A technical history of the Rio Tinto Mines: some notes on exploitation from pre-Phoenician times to the 1950s. The Institution of Mining and Metallurgy (IMM). London.

Tylecote, R. F., 1987. The early history of metallurgy in Europe. Longman, London. 